\title{
Analysis of Scottish Duchenne and Becker muscular dystrophy families with dystrophin cDNA probes
}

\author{
A Cooke, W G Lanyon, D E Wilcox, E S Dornan, A Kataki, E F Gillard, A J M McWhinnie,
} A Morris, M A Ferguson-Smith, J M Connor

\begin{abstract}
One hundred and thirty-two Scottish families, representing the majority of currently known cases in this country with at least one living subject affected by DMD (110) or BMD (22), were studied with a series of cDNA probes excluding the $3^{\prime}$ region of the gene (probes 10-14). Using mainly HindIII digested DNA from affected males, 89 patients showed deletions which ranged from 1 to 32 HindIII fragments in size. Two patients were also detected with exon duplications. Abnormalities were found to be particularly concentrated in the area of probe cDNA 8, with 56 patients being deleted for at least one of the fragments detected by this probe. A second smaller concentration of deletions was found with probe 1-2a which showed 16 deletions and two duplications. The endpoints of cDNA deletions or duplications were determined with a maximum variability of one HindIII fragment in 83 patients, while the remaining eight patients had a single deletion endpoint defined. The deletions found in two of our patients appear to conflict with the previously stated exon order at the $5^{\prime}$ end of the gene. Although no specific deletion patterns were apparent for DMD, the deletions found in $\mathbf{1 3}$ of the BMD patients all included the most proximal $(10 \mathrm{~kb})$ fragment detected by probe 8.
\end{abstract}

Duchenne muscular dystrophy (DMD) is the commonest fatal $\mathrm{X}$ linked recessive disorder in the UK, affecting approximately 1 in 3300 males. ${ }^{1}$ Both it and the milder allelic Becker muscular dystrophy

\footnotetext{
University Department of Medical Genetics, Duncan Guthrie Institute, Yorkhill, Glasgow G3 8SJ.

A Cooke, W G Lanyon, D E Wilcox, E S Dornan, A Kataki, E F Gillard*, A J M McWhinnie, A Morris, M A FergusonSmith†, J M Connor

Correspondence to Dr Cooke.

*Present address: Hospital for Sick Children, 555 University Avenue, Toronto, Canada.

†Present address: Department of Pathology, University of Cambridge, Tennis Court Road, Cambridge CB2 1QP.
}

Received for publication 2 October 1989.

Accepted for publication 24 November 1989.
(BMD) result from mutations in the dystrophin gene. The cDNA sequence of the dystrophin gene has been determined $^{2}$ and it has been shown to be composed of a minimum of 60 exons, as it detects 65 HindIII fragments and five HindIII sites are known to be present in the cDNA sequence. ${ }^{3}$ By subdividing the cDNA into lengths of approximately $1 \mathrm{~kb}$, Koenig $e t$ $a l^{3}$ were able to deduce the $5^{\prime}$ to $3^{\prime}$ order of a significant number of the HindIII fragments, and to show that deletions were most common in the region of probes 7 and 8 , a finding which has been confirmed by the results of other groups. ${ }^{4-6}$

We wish to report our analysis of DNA from 132 Scottish families with DMD or BMD using the cDNA probes isolated by Koenig et al. ${ }^{1}$ These families represent the vast majority of cases in the entire country with a living or recently dead affected subject.

\section{Patients and methods}

PATIENTS

In Scotland there are 254 pedigrees known to have had at least one member affected by $X$ linked muscular dystrophy. Samples from unrelated patients with DMD (110) or BMD (22) were referred to our laboratory as we have responsibility for carrier detection and prenatal diagnosis of muscular dystrophy as part of the Scottish molecular genetics consortium. Each case was clinically assessed and investigated in one of the genetics clinics associated with the Scottish consortium. Muscle histology was undertaken in each of the index cases reported in this paper, and DMD was differentiated from BMD using the age at which the patients became chairbound, as discussed by Emery. ${ }^{1}$ None of the index cases of DMD was ambulant after 11.5 years of age, and of the BMD index patients the earliest age of loss of ambulation was $13 \cdot 4$ years.

Twenty-two pedigrees of definite BMD were ascertained after care was taken to exclude possible cases of autosomal recessive limb-girdle dystrophy. All index cases had calf hypertrophy and markedly raised serum creatine kinase (SCK) levels. Eight showed X linked inheritance, and one case with two affected sibs and three sporadic cases were included because female relatives were found to have carrier levels of SCK. A further isolated case was added after 
Table 1 cDNA abnormalities and clinical severity in definite cases of $B M D$.

\begin{tabular}{|c|c|c|c|c|c|c|c|}
\hline Case no & $\begin{array}{l}\text { X linked } \\
\text { criteria* }\end{array}$ & $\begin{array}{c}\text { Age at } \\
\text { onset }\end{array}$ & $\begin{array}{c}\text { Age in } \\
\text { chair }\end{array}$ & $\begin{array}{l}\text { Age last } \\
\text { seen }\end{array}$ & $\begin{array}{c}\text { Age at } \\
\text { death }\end{array}$ & Severity & $\begin{array}{l}\text { Fragment numbers } \\
\text { deleted (figs } 1 \text { and } 2 \text { ) } \\
\text { or duplicated }\end{array}$ \\
\hline $\begin{array}{r}1987 a \\
\text { b } \\
c \\
2161 \\
3468 a \\
\text { b } \\
c \\
3995 a \\
\text { b } \\
4002 a \\
\text { b } \\
4025 \\
4486 a \\
\text { b } \\
5097 a \\
\text { b } \\
5100 a \\
\text { b } \\
c \\
d \\
5190 a \\
\text { b } \\
5551 \\
7509 a \\
\text { b } \\
\text { c } \\
\text { d } \\
\text { e } \\
9773\end{array}$ & $\begin{array}{l}\mathbf{X} \\
\underset{\mathbf{X}}{\mathbf{X}} \\
\mathbf{X} \\
\mathbf{X} \\
\mathbf{C} \\
\mathbf{C} \\
\mathbf{X} \\
\mathbf{X}\end{array}$ & $\begin{array}{r}7 \\
12 \\
25 \\
7 \\
16 \\
3 \\
3 \\
35 \\
10 \\
31 \\
4 \\
7 \\
3 \\
4 \\
15 \\
5 \\
? \\
5 \\
2 \\
1 \\
19 \\
4 \\
4 \\
? \\
3 \\
11 \\
6 \\
6 \\
2\end{array}$ & $\begin{array}{l}14 \\
18 \\
\\
30 \\
16 \\
16 \\
? \\
12 \\
14 \\
16 \\
42\end{array}$ & $\begin{array}{l}28 \\
12 \\
70 \\
24 \\
20 \\
69 \\
21 \\
21 \\
\\
25 \\
18\end{array}$ & $\begin{array}{l}59 \\
\\
38 \\
24 \\
\\
38 \\
\\
36 \\
29 \\
36\end{array}$ & $\begin{array}{l}\text { Severe } \\
\text { Moderate } \\
\text { Mild } \\
\text { Moderate } \\
\text { Mild } \\
\text { Moderate } \\
\text { Moderate } \\
\text { Mild } \\
\text { Moderate } \\
\text { Mild } \\
\text { Moderate } \\
\text { Severe } \\
\text { Severe } \\
\text { Moderate } \\
\text { Moderate } \\
\text { Severe } \\
\text { ? } \\
\text { Severe } \\
\text { Severe } \\
\text { Severe } \\
\text { Moderate } \\
\\
\text { ? } \\
\text { Severe } \\
\text { Moderate } \\
\text { Severe } \\
\text { Severe } \\
\text { Severe }\end{array}$ & $\begin{array}{l}\text { No deletion } \\
\text { Not done } \\
\text { No deletion } \\
\text { 33-38 } \\
33-35 \\
\text { Not done } \\
33-35 \\
33-35 \\
33-35 \\
\text { Not done } \\
33-35 \\
7 \\
\text { Not done } \\
\text { No deletion } \\
\text { Not done } \\
5-8 \\
\text { Not done } \\
\text { Not done } \\
\text { Not done } \\
\text { No deletion } \\
\text { 33-35 } \\
\text { 33-35 } \\
\text { 36 and } 37 \\
\text { Not done } \\
\text { Not done } \\
\text { 3-13 } \\
\text { Not done } \\
\text { Not done } \\
\text { 3-13 }\end{array}$ \\
\hline $\begin{array}{l}3816 \\
4477 \\
4051 \\
5165 a \\
\quad b \\
7805 \\
7883 \\
9421 \\
9768 a \\
\quad b \\
9772\end{array}$ & $\begin{array}{l}\text { D } \\
\mathbf{D} \\
\mathbf{D} \\
\mathbf{D} \\
\mathbf{D} \\
\mathbf{D} \\
\mathbf{D} \\
\mathbf{D} \\
\mathbf{D}\end{array}$ & $\begin{array}{r}15 \\
16 \\
4 \\
7 \\
9 \\
24 \\
10 \\
18 \\
17 \\
15 \\
20\end{array}$ & $\begin{array}{l}13 \\
13\end{array}$ & $\begin{array}{l}23 \\
35 \\
38 \\
23 \\
20 \\
35 \\
16 \\
24 \\
24 \\
21 \\
43\end{array}$ & & $\begin{array}{l}\text { Mild } \\
\text { Mild } \\
\text { Moderate } \\
\text { Severe } \\
\text { Severe } \\
\text { Mild } \\
\text { Moderate } \\
\text { Mild } \\
\text { Mild } \\
\text { Mild } \\
\text { Mild }\end{array}$ & $\begin{array}{l}35-39 \\
33-37 \\
36-38 \\
\text { Not done } \\
3,5-7,+? 4 \\
33-35 \\
33-35 \\
33-35 \\
33-35 \\
\text { Not done } \\
33-37\end{array}$ \\
\hline
\end{tabular}

${ }^{*} \mathrm{X}=$ affected males in $>1$ sibship; $\mathrm{C}=$ affected male(s) in 1 sibship +female(s) with carrier levels of SCK; $\mathrm{P}=$ abnormal dystrophin; $\mathrm{D}=$ deletion found.

abnormal dystrophin was found after muscle biopsy. Seven sporadic cases and two pairs of isolated sibs were included only after they were found to have a cDNA deletion. A further three pedigrees (cases 7327,7484 , and 8337 ) of possible sporadic BMD were excluded from this study as no deletion was found and no other evidence of $\mathrm{X}$ linked inheritance was shown.

Each subject affected by BMD was graded for severity (table 1). The age at which ambulation was lost proved to be the best guide. Age of onset was influenced by previous family history, and in one case by an incidental finding of raised SCK. Age of death was very variable and causes ranged from pneumonia to the crashing of an electric chair (two), suicide, drowning, and pneumothorax, all related to BMD but often affecting the more active patients. In general, those chairbound in their teens were graded as severe, those between 20 and $\mathbf{4 5}$ as moderate, and those after 45 as mild. Two sporadic, presumed BMD patients under the age of 12 had a further muscle biopsy for dystrophin assay to distinguish them from DMD.

\section{DNA EXTRACTION}

DNA was isolated from either peripheral lymphocytes or from Epstein-Barr virus transformed lymphoblastoid cell lines. The karyotypes of all cell lines used were checked by cytogenetic analysis to confirm that they had retained their normal diploid state.

\section{GENOMIC PROBES}

The majority of the patients in this study were also investigated with a number of genomic probes: $754{ }^{7}$ HIP25, ${ }^{8}$ XJ series, ${ }^{9}$ pERT series, ${ }^{10} \mathrm{~J}-\mathrm{Bir},{ }^{11}$ P20, ${ }^{12}$ GMGX $11,{ }^{13}$ and J66. ${ }^{14}$

\section{cDNA ANALYSIS}

Digests for cDNA analysis were carried out using (mainly) HindIII and $B g I I I$ restriction enzymes and samples were run out on $1 \%$ agarose gels, 20 to $24 \mathrm{~cm}$ in length, to facilitate resolution of the numerous bands encountered with most of the cDNA probes. 
Table 2 Frequency of deletions detected with each of the cDNA probes tested.

\begin{tabular}{lccc}
\hline Probe & No tested & $\begin{array}{c}\text { Deletions } \\
\text { detected }\end{array}$ & $\begin{array}{c}\text { Overall total } \\
\text { of deletions }\end{array}$ \\
\hline $1-2 \mathrm{a}$ & 124 & $16(+2)^{*}$ & $16(+2)$ \\
$2 \mathrm{~b}-3$ & 111 & $14(+1)^{*}$ & $22(+2)$ \\
$4-5 \mathrm{a}$ & 101 & 9 & $24(+2)$ \\
$5 \mathrm{~b}-7$ & 120 & 37 & $57(+2)$ \\
8 & 132 & 56 & $86(+2)$ \\
9 & 85 & 13 & $89(+2)$ \\
\hline
\end{tabular}

*Duplications also found with these probes. The increase in the overall total of deletions reflects new deletions found with each probe in a 5'-3' direction.

Table 3 Frequency of deletions and bandshifts detected in $D M D$ and $B M D$ patients with genomic probes.

\begin{tabular}{lccc}
\hline Probe & No tested & Deletions & Bandshifts \\
\hline 754 (DXS84) & 83 & 1 & - \\
HIP25 $(D X S 230)$ & 72 & 6 & - \\
XJ series $(D X S 206)$ & 84 & 7 & - \\
pERT series $(D X S 164)$ & 97 & 7 & - \\
J-Bir $(D X S 270)$ & 104 & 3 & 1 \\
P20 $(D X S 269)$ & 104 & 7 & 9 \\
GMGX11 (DXS239) & 106 & 13 & 5 \\
J66 $(D X S 268)$ & 105 & - & 1 \\
\hline
\end{tabular}

After electrophoresis, DNA was transferred to Hybond membranes (Amersham) and prepared for hybridisation. DMD cDNA probes 1-2a, 2b-3, 4-5a, $5 \mathrm{~b}-7,8$, and 9-14 were obtained from the American Type Culture Collection. Plasmids were prepared from cesium chloride density gradients, ${ }^{15}$ and inserts isolated from low melting point agarose gels (FMC BioProducts). cDNA 9-14 was digested with BamHI to separate the individual probes 9,10 , and 11-14. Probes were labelled using a random primed oligonucleotide system (Amersham).

\section{Results}

DNA samples from affected males were digested with HindIII and probed initially with cDNA 8, followed by 1-2a. BglII digests were also carried out and examined mainly with probes 5b-7 and 9, which provided confirmation of the presence (or absence) of weakly hybridising $H$ ind III fragments. ${ }^{4}$

The number of patients tested with each probe and the frequency of deletions detected are shown in table 2. The total number of abnormalities detected was 91 (89 deletions and two duplications) out of 132 patients (69\%). By far the majority of the abnormalities were

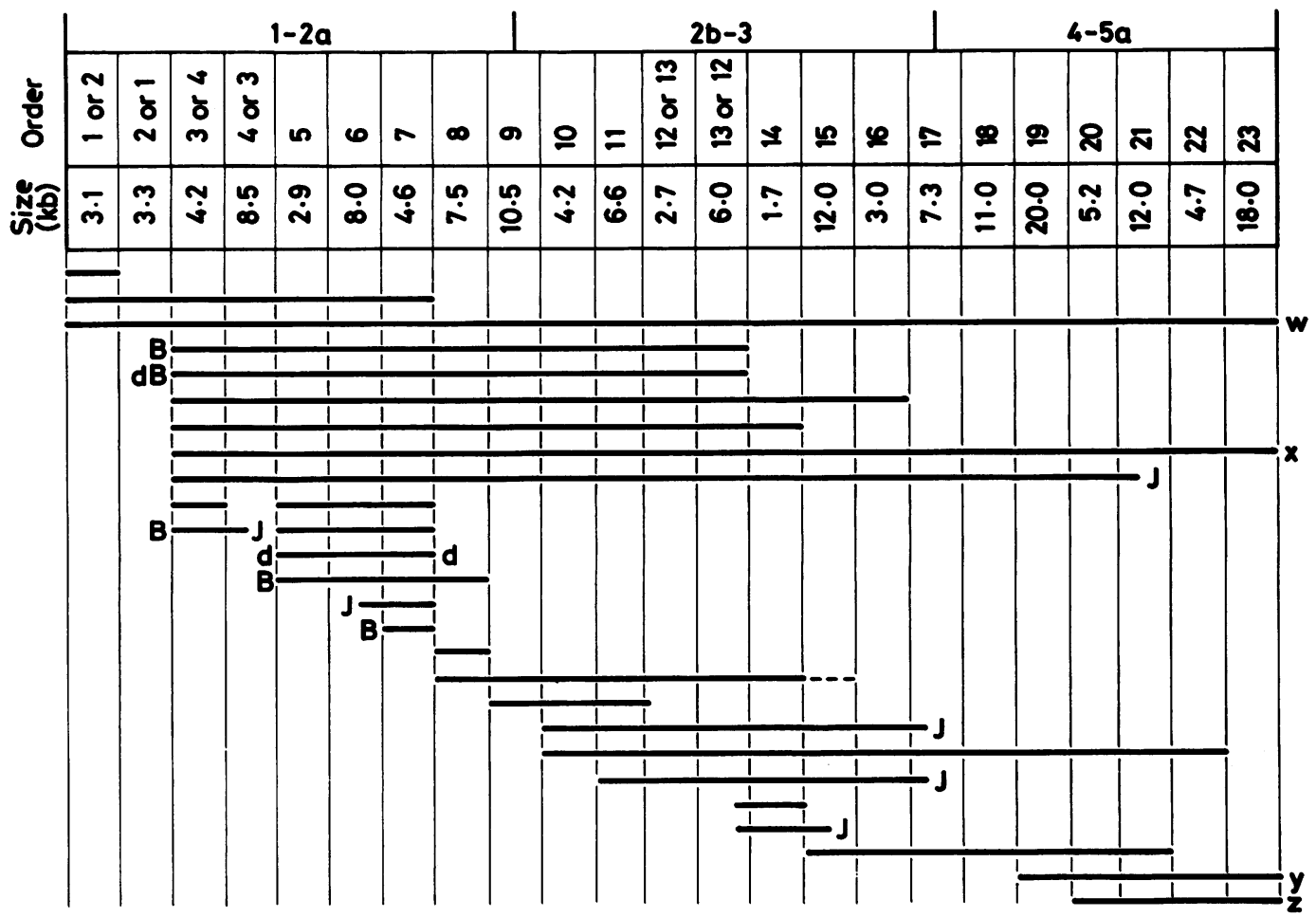

Figure 1 HindIII fragment deletions detected with probes $1-2 a, 2 b-3$, and $4-5 a . B=B M D ; d=d u p l i c a t i o n ; \mathcal{F}=b a n d s h i f t ; b r o k e n$ line $=$ uncertain endpoint; $w, x, y$, and $z=$ deletions extending into probe $5 b-7$. 
found with probe 8 (56 out of 91 or $61 \%$ ), with a significant proportion of these ( 26 out of 56 or $46 \%$ ) extending into the distal segment of probe $5 \mathrm{~b}-7$. A second, smaller concentration of deletions and the two duplications detected were found in the proximal region of the gene corresponding to probe $1-2 \mathrm{a}$ (18 out of 91 or $20 \%$ ). The smaller number of samples tested with probes 4-5a and 9 in particular is mainly a consequence of patients with an already defined deletion not being examined with these probes.

Seventeen patients were shown to be deleted for only a single $H$ indIII fragment, including five cases with a bandshift in an adjacent fragment. The largest deletion in our series ( $32 \mathrm{HindIII}$ fragments) extends well beyond the DMD gene in the direction of the centromere (approximately 4 million base pairs in total) and was the subject of a previous report. ${ }^{16}$ The largest deletion found that was contained within the boundaries of the DMD gene comprised 30 HindIII fragments.
Thirty-nine of the patients with a cDNA deletion had previously been shown to have a deletion or bandshift with at least one of the series of genomic probes shown in table 3.

DELETION ENDPOINTS AND ORDER OF HindIII FRAGMENTS Precise endpoints of deletions (in terms of HindIII fragments) were obtained in 72 cases, while in a further 11 patients one endpoint was precisely defined with the other subject to a maximum variability of a single fragment. Three patients had one deletion endpoint proximal to exon 1, and two patients were negative for the most distal fragment detected by probe 9. The endpoints of deletions found with probes $1-2 a, 2 b-3$, and 4-5a, which together detect a total of 23 HindIII fragments, are shown in fig 1 , and those found with $5 \mathrm{~b}-7,8$, and 9 (detecting 26 HindIII fragments) in fig 2 . One HindIII fragment $(18 \mathrm{~kb})$ is common to probes $4-5 \mathrm{a}$ and $5 \mathrm{~b}-7$, and four deletions,

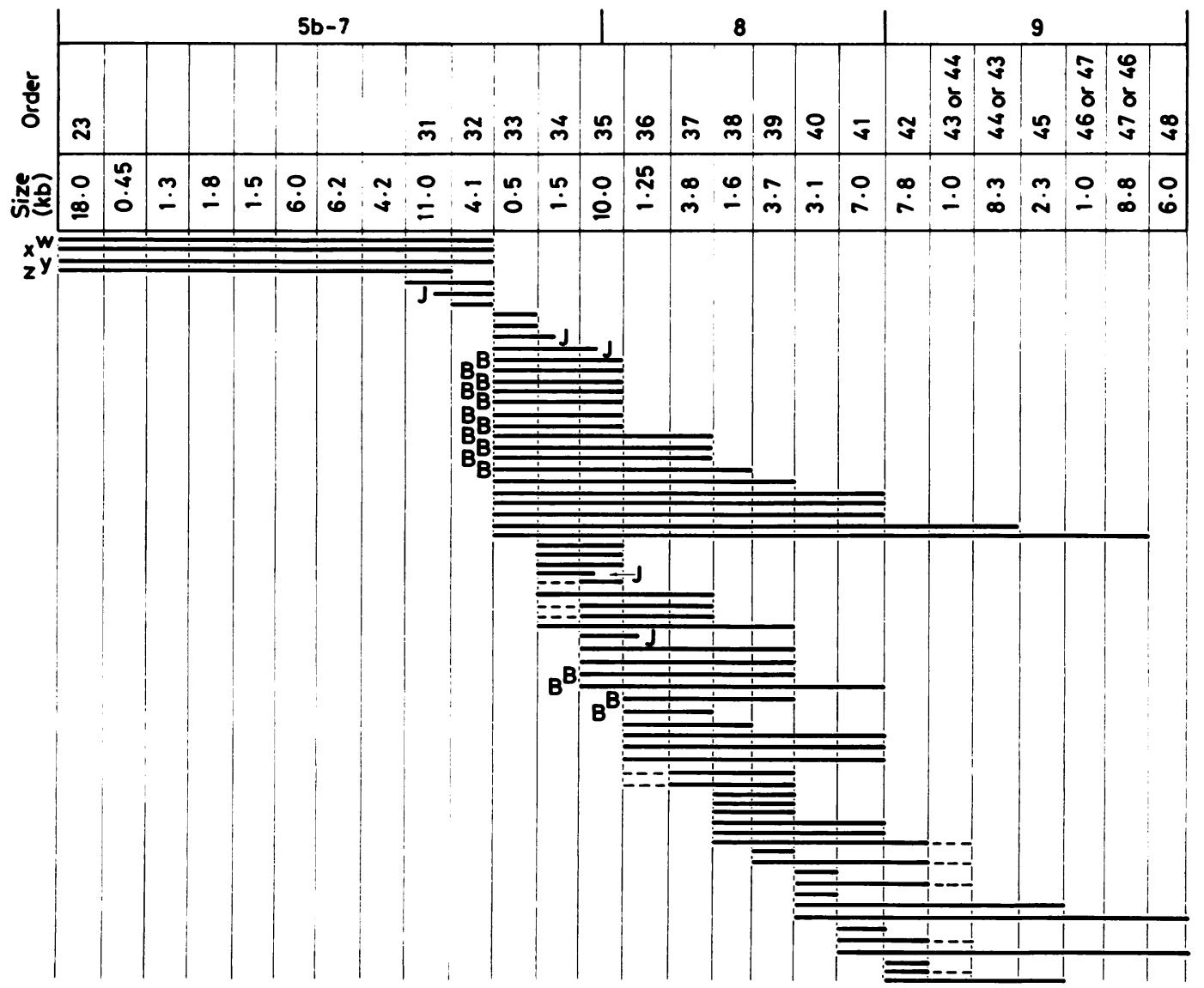

Figure 2 HindIII fragment deletions detected with probes $5 b-7,8$, and $9 . B=B M D ; \mathcal{F}=$ bandshift; broken line $=$ uncertain endpoint; $w, x, y$, and $z=$ deletions also found with more proximal probes. 
originating in the first part of the gene, end in the more distal section. The HindIII fragments are listed in the order given in previous publications, ${ }^{3-5}$ or as indicated on the information sheets supplied with the probes from ATCC. The order numbers for the HindIII fragments shown are those that can be determined from our series of deleted patients.

The three smallest HindIII fragments detected by probe $1-2$ a have been stated to be $3 \cdot 1,3 \cdot 2$, and $3 \cdot 25$ $\mathrm{kb}$ in size, representing exons 5,1 , and 2 respectively. ${ }^{2}$ Under our conditions the sizes of these bands appear to be approximately $2 \cdot 9,3 \cdot 1$, and $3.3 \mathrm{~kb}$. Two patients (DMD case 0120 and BMD case 5165) have also produced results which appear to conflict with the stated order of the $4.2 \mathrm{~kb}$ and $8.5 \mathrm{~kb}$ fragments detected by probe 1-2a, which are said to be exons 3 and 4 respectively (fig 1 ). One of the patients (case 0120 ) shown in track 4 in fig 3 is clearly deleted for the $4.2 \mathrm{~kb}$ band but appears positive for the $8.5 \mathrm{~kb}$ band. In total, 62 of the deletions detected in our patients are located in the area of probes 7 and 8 , which consists of less than $10 \%$ of the entire cDNA. A large number of patients was also found to have a deletion endpoint in the intron between the 4.1 and $0.5 \mathrm{~kb}$ HindIII fragments detected by probe $5 \mathrm{~b}-7$ (21 with proximal endpoint and six with distal endpoint). None of the patients deleted for any part of probe 8 in our series had an endpoint proximal to this intron, which has also been shown to be the hybridisation site of the genomic probe P20. ${ }^{12}$

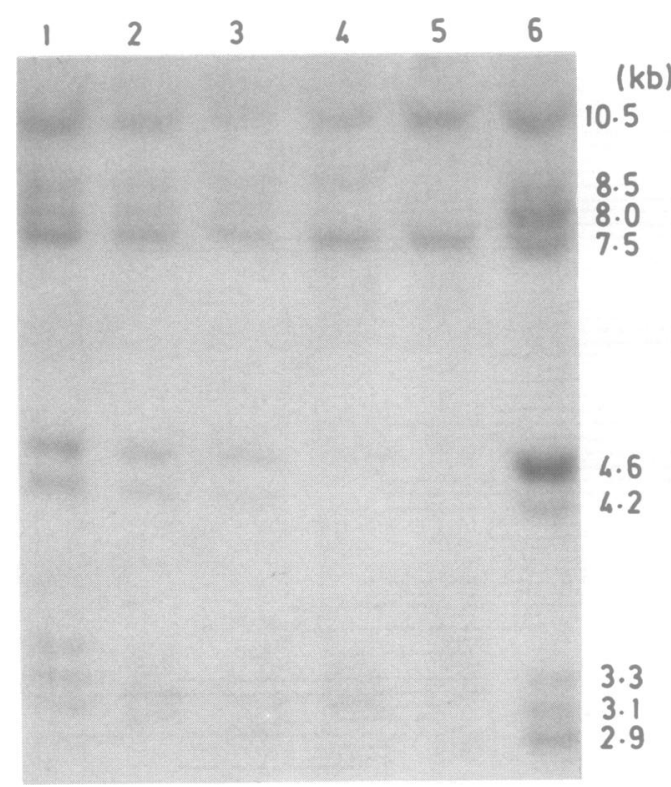

Figure 3 HindIII digested DNA probed with cDNA 1-2a. Tracks 4 and 5 show deletions and track 6 shows a duplication.
SPECIFIC DELETION TRENDS ASSOCIATED WITH DMD OR BMD

Apart from the concentration in the region of probe 8, no particular trend of deletions was apparent in our DMD patients. Proximal DMD deletion endpoints were found for each of the HindIII fragments detected by probe 8 (apart from $3.8 \mathrm{~kb}$ ) producing a step-like pattern (fig 2).

The abnormalities found in 13 out of the 18 deleted BMD patients, however, all included the $10 \mathrm{~kb}$ fragment detected by probe 8 (fig 2) and those detected in four of the remaining BMD patients included the $4.6 \mathrm{~kb}$ band detected by probe $1-2 \mathrm{a}$ (fig 1). This finding with BMD contrasts with the situation observed in DMD, where only 20 patients (including two with bandshifts) were deleted for the $10 \mathrm{~kb}$ band detected with probe 8 , while 22 patients were deleted for other fragments detected by this probe.

\section{Discussion}

The frequency of cDNA deletions observed in Scottish DMD patients was 71 (+ one duplication) out of 110 pedigrees $(65 \%)$, which is similar to that reported by other groups. ${ }^{417}$ In addition, nine deletions and one duplication were detected out of 13 pedigrees with definite $\mathrm{X}$ linked $\mathrm{BMD}$, and a further nine out of 12 pedigrees with possible BMD also had deletions (table 1).

Definition of the endpoints of deletions has been possible in most of the patients and these have generally confirmed the order of HindIII fragments in the gene reported by other workers. The one possible exception to this is the stated order of exons 3 and 4 which may conflict with the results observed in two of our patients.

The concentration of deletions in the area of probes 7 and 8 is in agreement with previous reports, ${ }^{3-6}$ and also our results with the genomic probes P20 and GMGX11 (table 3) which map to this region of the gene. The large number of patients with deletion endpoints in the intron containing P20 seen in this study is a feature which has also been observed by other workers. ${ }^{4-6}$

\section{CORRELATION OF DELETION AND PHENOTYPE}

Norman et $a l^{5}$ suggested that the common BMD deletion (fragments 33 to 35 , fig 2 ) is associated with a mild phenotype. In general our results support this. From seven BMD pedigrees carrying this deletion in our series, 12 subjects were found (table 1). Age of onset ranged from 3 to 35 years with a median of 13 years. One patient died at the age of 59 while still ambulant. The other 11 ranged in age from 4 to 70 with a median age of 24 years. Only three were using wheelchairs, from ages 42,57 , and 62 , respectively. 
Apart from the common deletion of fragments 33 to 35 seen in BMD, we have failed to correlate clinical severity with the breakpoints of the deletions. Not only do different pedigrees with the same apparent deletion show widely differing phenotypes (for example, fragments 35 to 39 deleted in BMD case 3816 (table 1) and two typical DMD cases (5538 and $5561)$ ), but there are substantial variations in clinical severity within individual pedigrees where each affected subject will presumably have the same deletion at this level of resolution (for example, BMD cases 1987 and 7509 , table 1). We have previously reported $^{16}$ two cousins with DMD (case 5099) who have the same large deletion detectable by cytogenetic and flow analysis who also showed a considerable difference in clinical severity.

This variation between similar deletions and within the same family suggests that the final phenotype in $\mathrm{X}$ linked muscular dystrophy is influenced by factors in addition to the observed deletions within Xp21. Clinicians should be wary of attempting to give a prognosis based solely on the site and size of cDNA deletions. The exception to this may be in the counselling of parents of an isolated case with onset in early childhood. The finding of a deletion of the 0.5 , 1.5 , and $10 \mathrm{~kb}$ fragments (33-35, fig 2) would favour a diagnosis of BMD rather than DMD.

We thank Dr L Kunkel, Professor P Pearson, Dr R Worton, and Dr K Davies for generously donating probes. We are grateful to families and their clinicians from throughout Scotland for providing us with relevant samples and information on patients. We thank Dr J Heckmatt for the two dystrophin biopsy results. This study was supported by the Muscular Dystrophy Group of Great Britain, by the Scottish Home and Health Department (New Developments in Health Care Programme), by the MRC (EFG), and by the Greek Government State Scholarship Foundation (AK).
1 Emery AEH. Duchenne muscular dystrophy. Oxford: Oxford University Press, 1987.

2 Koenig M, Monaco AP, Kunkel LM. The complete sequence of dystrophin predicts a rod-shaped cytoskeletal protein. Cell 1988;53:219-28.

3 Koenig M, Hoffman EP, Bertelson CJ, Monaco AP, Feener C, Kunkel LM. Complete cloning of the Duchenne muscular dystrophy (DMD) CDNA and preliminary genomic organisation of the DMD gene in normal and affected individuals. Cell 1987;50:509-17.

4 Darras BT, Blattner P, Harper JF, Spiro AJ, Alter S, Francke U. Intragenic deletions in 21 Duchenne muscular dystrophy (DMD)/Becker muscular dystrophy (BMD) families studied with the dystrophin cDNA: location of breakpoints on HindIII and BgIII exon-containing fragment maps, meiotic and mitotic origin of the mutations. Am f Hum Genet 1988;43:620-9.

5 Norman A, Thomas N, Coakley J, Harper P. Distinction of Becker from limb-girdle muscular dystrophy by means of dystrophin cDNA probes. Lancet 1989;i:466-8.

6 Liechti-Gallati S, Koenig M, Kunkel LM, et al. Molecular deletion patterns in Duchenne and Becker type muscular dystrophy. Hum Genet 1989;81:343-8.

7 Hofker MH, Wapenaar MC, Goor N, Bakker E, van Ommen GJB, Pearson PL. Isolation of probes detecting restriction fragment length polymorphisms from $X$ chromosome-specific libraries: potential use for diagnosis of Duchenne muscular dystrophy. Hum Genet 1985;70:148-56.

8 Smith TJ, Wilson LJ, Kenwrick SJ, et al. Isolation of a conserved sequence deleted in Duchenne muscular dystrophy patients. Nucleic Acids Res 1987;15:2167-74.

9 Ray PN, Belfall B, Duff C, et al. Cloning of the breakpoint of an $\mathrm{X} ; 21$ translocation associated with Duchenne muscular dystrophy. Nature 1985;318:672-5.

10 Kunkel LM, Monaco AP, Middlesworth W, Ochs HD, Latt SA. Specific cloning of DNA fragments absent from the DNA of a male patient with an X-chromosome deletion. Proc Natl Acad Sci USA 1985;82:4778-82.

11 Monaco AP, Bertelson CJ, Coletti-Feener C, Kunkel LM Localization and cloning of $\mathrm{Xp} 21$ deletion breakpoints involved in muscular dystrophy. Hum Genet 1987;75:221-7.

12 Wapenaar MC, Kievits T, Hart KA, et al. A deletion hot spot in the Duchenne muscular dystrophy gene. Genomics 1988;2: 101-8.

13 Gillard EF. Molecular analysis of Duchenne muscular dystrophy and other Xp mutations using cloned DNA sequences. PhD thesis, University of Glasgow, 1988.

14 van Ommen GJB, Bertelson C, Ginjaar HB, et al. Long range genomic map of the Duchenne muscular dystrophy (DMD) gene. Isolation and use of J66 (DXS268) a distal intragenic marker. Genomics 1987;1:329-36.

15 Maniatis T, Fritsch EF, Sambrook J. Molecular cloning: a laboratory manual. New York: Cold Spring Harbor Laboratory, 1982.

16 Wilcox DE, Cooke A, Colgan J, et al. Duchenne muscular dystrophy due to familial Xp21 deletion detectable by DNA analysis and flow cytometry. Hum Genet 1986;73:175-80.

17 Forrest SM, Cross GS, Speer A, Gardner-Medwin D, Burn J, Davies KE. Preferential deletion of exons in Duchenne and Becker muscular dystrophies. Nature 1987;329:638-40. 